\title{
Effects Of Credit Information Sharing On Performance of Savings And Credit Cooperative Societies In Kenya
}

\author{
Otiende Wellington Anjawo \\ School of Human Resource Development, \\ Department of Entrepreneurship and Procurement, Leadership and management, \\ Jomo Kenyatta University of Agriculture and Technology, Nairobi Kenya. \\ Dr. Elizabeth Nambuswa Makokha \\ School of Human Resource Development, \\ Department of Entrepreneurship and Procurement, Leadership and management. \\ Jomo Kenyatta University of Agriculture and Technology, Nairobi Kenya
}

\begin{abstract}
The purpose of the study was to analyse the effect of credit information sharing on the performance of Saccos in Kenya. The specific objective was; to identify the effect of credit rating on performance of saccos in Kenya, The study was anchored on Information Asymmetry Theory, Credit Rationing Theory and Transaction Cost Theory. The research used a descriptive survey research design. The population for this study was the 60 Saccos with head offices in Nairobi Kenya, from where the researcher targeted the credit managers as the respondents of the study. This study was a census survey. The study used both primary and secondary data. The primary data was collected through a questionnaire from the credit managers of the 60 Saccos while secondary data was retrieved from the SASRA's Sacco supervision annual reports for the respective years. The quantitative data was analysed using both descriptive and inferential statistics. Both correlation and multiple linear regression analysis method were used to analyze the relationship between the study variables. The study findings showed that a significant positive relationship between credit rating and the performance of Saccos in Kenya $(\beta=0.719$ and $P$ value $<0.05)$. The study concluded that credit rating, played a significant role in enhancing the performance of Saccos in Kenya due to their centrality in the Saccos' lending decisions. The study recommends that Saccos in Kenya should cross reference the information they hold about clients with information held by the CRBs in order to enhance their credit rating activities when evaluating a client's suitability for loans applied. The study also recommends that Saccos in Kenya should review their lending policies to ensure that they promote timely repayment of monies given out as loans to various borrowers. The study will be of significance to many stakeholders; members/customers will both benefit from increased loanable funds as well as increased dividends. The government is likely to receive higher revenue arising from taxes while the citizenry may benefit from employment opportunities occasioned by a well performing Sacco.
\end{abstract}

\section{INTRODUCTION}

Credit Information Sharing is the exchange of information on client financial history, the information contained is on borrowers' characteristics which include the credit history, credit worthiness and current debt level of the borrower (Jappelli \& Pagano, 2010). Sharing of credit information can make an important contribution to the development of the financial system which is an important determinant of economic growth (Furletti, 2012). Credit scores have immense benefits to both lenders and borrowers. Borrowers are able to negotiate with lenders on better terms. Highly rated borrowers with good credit history can convincingly negotiate for lower interest rates or even waiver of collateral. Credit reference bureaus are agencies that researches and collects individual credit information and sells it for a fee to creditors so that 
they can make a decision on granting loans. Typical clients include banks, mortgage lenders, credit card companies and other financing companies (Sacerdoti, 2010).

Credit information sharing began in the USA before being used in Europe in the early 1960s. In those days, credit bureaus were in most cases privately owned, independent companies, whose shareholders were banks and financial firms. In the United States the Fair Credit Reporting Act of 1970, amended in 1996, stated that credit reporting agencies may distribute individual credit reports either with the consumer's authority or for a legitimate business need in connection with a business transaction that is initiated by the consumer, or to review an account to determine whether the consumer continues to meet the terms of the account. The act also prohibited dissemination of adverse information (such as bankruptcy) that is more than seven years old. Today in the USA and many other countries financial institutions are allowed to share credit information concerning their customers freely unlike in the past in order to reduce credit risk (Klein, 2012).

Across the globe, as is evident mainly in developed countries such as United Kingdom, Germany, Japan, Australia and the Netherlands, effective Credit Information Sharing can only be fully achieved by compulsory sharing within the confines of a legal framework that respects the confidentiality of the information shared among market participants and levels the playing field for different financial institutions (IMF, 2009). In a number of countries, lenders (banks, finance companies, credit card companies, retailers, suppliers extending trade credit) routinely share information on the creditworthiness of their borrowers through credit bureaus. The bureaus collate information with data from sources like courts, public registers and tax authorities and compiles files on borrowers. Lenders then obtain a consolidated data about a credit applicant by requesting a credit report from the bureaus (Jappelli \& Pagano, 2010).

CRBs thrive in a good legal environment where there is data protection law, a fair credit reporting law, a data retention law, consumer protection and admissibility of electronic evidence and certification of electronic signatures, without which credit reporting become a shenanigan (Sacerdoti, 2010). CRBs were introduced to assess the credit worthiness of the loan applicants. They complement the central role played by banks and other financial institutions in extending financial services within an economy. They help lenders make faster and more accurate credit decisions. They collect, manage and disseminate customer information to lenders within a provided regulatory framework.

Credit histories not only provide necessary input for credit underwriting, but also allow borrowers to take their credit history from one financial institution to another, thereby making lending markets more competitive and, in the end, more affordable. Credit bureaus assist in making credit accessible to more people, and enabling lenders and businesses reduce risk and fraud.It has been found out that in order to minimize loan losses thus credit risk, it is essential for commercial banks to have effective credit risk management systems in place (Jappelli \& Pagano, 2010). Given the asymmetric information that exists between lenders and borrowers, financial institutions must have a mechanism that ensures that they not only evaluate default risk that is unknown to them in order to avoid adverse selection, but also that can evolve in order to avoid moral hazards (Stiglitz \& Weiss, 2008).

CRBs are institutional solutions to these two ubiquitous problems in lending, adverse selection and moral hazard. CRBs are meant to provide to the credit industry and the market, organized information on the performance of borrowers (Donge, 2012). An effective system that ensures repayment of loans by borrowers is critical in dealing with asymmetric information problems 
and in reducing the level of loan losses, thus the long term success of any banking organization. Credit risk management is essential in optimizing the performance of financial institutions (Brown \& Zehnder, 2016).

According to reviews conducted in Egypt, Nigeria and South Africa on performance of lenders, it was acknowledged that information sharing creates incentives for borrowers to perform in line with banks' interests and that information sharing can drive borrowers to repay loans when the legal environment makes it difficult for banks to enforce credit contracts (Brown, Jappelli \& Pagano, 2017). As such, by exchanging information about their customers, banks can improve their knowledge of applicants' characteristics, past behavior and current debt exposure. In a review focusing on the critical factors of effective lending in Zambia, it was held that information sharing reduces informational asymmetries, which in turn reduces adverse selection obstacles in lending, as well as change borrowers' motives to repay, both directly and by adjusting the competitiveness of the credit market (Brown et al., 2017). Gietzen (2016) in a study done in Cote D'voire posited that information sharing efficiently mitigates adverse selection problems since information sharing facilitates tracing borrowers who switch banks.

In a study carried out in Tunisia on information sharing and information acquisition in the country's credit markets by Karapetyan and Stacescu (2010), it was established that information sharing provide more accurate lending decisions, provide higher welfare, which leads to an increased locus on relationship banking, and favor informationally opaque borrowers. In a related review in Libya, McIntosh and Wydick (2014) observed that credit information systems first create a screening effect that advances risk evaluation of loan applicants, thereby raising portfolio quality, which, in turn, reduces rates of arrears. Similarly, Jappelli and Pagano (2010) in a study on information sharing, lending and defaults in South Africa revealed that bank lending had gone up and credit risk lowered following introduction of credit information sharing among both private or public lending agencies.

However, in Sudan it was that there was a negative effect on credit information sharing on nonperforming loans given that the level of non-performing loans tends to reduce with increase in credit information sharing (Ismael, 2015). However in Tanzania, Mburuti (2017) while analyzing how systems integrity in credit information sharing practices affected the administration of credit risk in commercial banks revealed that the system integrity in credit information sharing significantly affected the management of credit risk in turn affecting access to credit among loan consumers. Similarly, Kiragama (2016) in Rwanda found evidence to the effect that sharing of credit information influenced the level of non-performing loans among the financial institutions as it helped the institutions to decline lending to chronic defaulters.

Credit information sharing is a relatively new concept in Kenya: Banking (credit reference bureau) regulations 2008 that govern licensing, operation and supervision of credit bureaus by Central Bank of Kenya were gazetted and operationalized in 2009 (Oludhe, 2011). The Central Bank of Kenya has licensed two Credit Reference Bureaus i.e. Credit Reference Bureau Africa Limited and Metropol Credit Reference Bureau Limited (Kabiru, 2014).

For many years, Kenyan banks have had to contend with having incomplete information about borrowers that in turn translated to higher risk premiums on interest rates. Bank industry players also say lack of credit reference information leads to a risk of overpricing low risk borrowers and under-pricing high risk borrowers. The Central Bank of Kenya (CBK) is processing licences for new credit reference bureaus to step up sharing of borrowers' information among banks. Perennial defaulters had been the cause of high lending rates 
(Rukwaro, 2011). Credit information sharing is a mechanism introduced by Central Bank requiring all banks to share data on the credit history of their customers. This information is shared by banks through credit reference bureaus when they want to establish the credit worthiness of a customer seeking a loan.

Banks and other credit providers use credit reports obtained from credit bureaus as part of the lending decision process. Walsh (2003) warns that having only one half of the picture (negative information) runs the risk of it becoming the only deciding factor - a blacklist with the potential of restricting access to credit. In the past, credit scoring focused on measuring the risk that a customer would not fulfil his/her financial obligations and run into payment arrears. More recently, credit scoring evolved to loss and exposure risk as well (Glennon et al., 2008). Scoring techniques are nowadays used throughout the whole life cycle of a credit as a decision support tool or automated decision algorithm for large customer bases. With increasing competition, electronic sale channels and recent saving, credit and cooperative regulations have been important catalysts for the application of semi- automated scoring systems.

Credit Reference Bureaus (CRBs) gather information on the payment history and accounts of borrowers. CRBs collect and distribute two major types of data i.e. 'white' and 'black' information. 'Black' information usually refers to negative consumer data, (information about defaults on payments, delays, delinquencies, bankruptcies etc) that is, information with a negative connotation on the payment history and the financial behavior of the data subject. White information on the other hand is positive consumer data on payment history and the financial behavior of the data subject, credit report depends on the amount of detail of the information (La Porta, Florencio, Andrei \& Robert, 2007).

Credit Information Sharing (CIS) Kenya launched its 2015-2019 Strategic Plans in late October 2014. The Plan firmly shares in this belief, and is reflective of recent debates and conversations around financial inclusion and access to affordable credit. This strategy is thus designed to place CIS Kenya at the centre of transforming Africa's credit market and to improve its quality. Motivated by the desire to realize the full benefits of CIS in the next five years, the Strategy seeks to entrench the use of credit reports part of routine credit management by both lenders and borrowers. Moreover, this Strategy takes cognizance of the need to bring regulators, financial service providers and credit reporting providers together around a model that works for all (CRB, 2016).

Credit systems can be improved to enhance access to credit in Kenya. Upcoming innovations that sought to accomplish this phenomenon inspired the 3rd Regional CIS Conference, whose theme was "CIS for Innovation and Financial Inclusion, Mikopo Kisasa!" Translated from Swahili, "Mikopo Kisasa" means "Contemporary Lending Approaches". The conference was held on February 2016 in Nairobi, Kenya. CIS Kenya played host to 300 executive delegates representing various segments of credit markets from the EAC Region and beyond. The event was followed by the Nairobi Business Community Summit, providing half day sensitization on CIS to 400 bank staff and credit consumers respectively on each day. The events had an interesting and informative agenda that was facilitated by renowned global experts who shared insights on fundamental aspects of CIS that stand vital in managing credit risk (CRB, 2016).

The stability of the economy has greatly been obstructed by the high level of non-performing loans in the banks. In March $31^{\text {st }} 2014$, there was an increase of $7.8 \%$ which was KShs.73 
billion in NPLs stock compared to 68.3 billion in 2013 as indicated by the CBK (2015). At the end of 2001, Kenya's NPLs stood at KShs 107 billion. As noted by (Kusi \& Okoth, 2013) that figure represented 38\% of the total loan which was 281.7 billion shillings in the banking sector. A total of Sh228 billion loan books and deposits of Sh205 billion are held by the 184 licensed SACCOs in Kenya. SACCOs also hold upto KShs. 15 billion of the total non-performing loans (CBK, 2017). This shows that the borrowers have good credit records hence their access to these credit facilities. Due to bad loans, it has been observed that most of the defaulters have been shifting to the SACCOs. Instead of blacklisting defaulters using CRB reports, sharing of positive information by SACCOS would be helpful in putting pressure on the lending organizations and rewarding of borrowers who repay in good time. When a Sacco's liquidity is affected, then the loans are termed as non-performing (CBK Annual Banks Supervision Report, 2016).

This incidence of bad loans was worrying and put to question the credit models and quality of information employed by credit analysts. Net loans at the level of Kshs. 315 billion as at December 31, 2009 accounted for 51\% of total net assets of Kenya's banking sector. At the same time the proportion of non-performing loans to total loans in Kenya was at a high of 30\% as at 31st December 2014. NPLs amounted to Shs.94 billion (Oloo, 2015). Comparing, the ratio of non-performing loans to total loans (NPLS/TL) in Kenya of 33\% to similar African economies at the end of 2008, central banks of those countries (by then) reported that, this ratio (NPLs/TL) was much lower in Zimbabwe (24\%), Nigeria (11\%), and South Africa (3\%) (CBK, 2008). It's against this backdrop that the Banking (Credit Reference Bureau) Regulations 2008, that govern licensing, operation and supervision of CRBs by the CBK were gazetted and operationalized in 2009 (Waweru \& Kalani, 2009).

A number of studies had been done on credit information sharing in Kenya. However, their focus had been on the link that existed between credit information sharing and performance in the commercial banks of Kenya. A study by Aduda (2011) showed that the performance of banks greatly improved due to the licensing of the CRBs on the connection between credit information sharing and profitability. It was also found out by Oludhe (2011) that credit risk management affected the financial performance of banks in Kenya and therefore concluded that there exists a positive relationship between the two. None of the above studies had focused on Saccos in Kenya. Again these studies were done more than 5 years ago and given that the financial sector is very dynamic, there was need for studies to be done on an ongoing basis. This study therefore aimed to fill the gap by establishing the effect of credit information sharing on performance of Saccos in Kenya. The general objective of the study was to analyze the effect of credit information sharing on performance of Saccos in Kenya.The specific objective of the study was to identify the effect of credit rating on performance of Saccos in Kenya.

\section{EFFECD OF CREDIT RATING ON PERFORMANCE OF SACCOS IN KENYA}

Credit rating refers to the process that banks and other lending financial institutions use to estimate the ability of a person or organization to fulfil their financial commitments, based on past dealings. It is therefore the judgment by a creditor on an individual or business' current and future ability and inclination to honor an obligation as agreed (Ozdemir \& Boran, 2008). Turner and Varghese (2008) studied the effects of credit rating on the eve of Brazilian credit reporting reforms. They targeted 28 commercial banks operating in Brazil. Descriptive research design was used. Secondary data was gathered from the central bank of Brazil and analysis done using descriptive statistics. The study revealed a positive relationship between credit rating and performance. This study was however conducted in Brazil which is a 
developed economy and where the citizens' ability to repay loans is higher. The current study focuses on Kenya which is a developing country.

Aduda, Magutu and Wangu (2012) studied the relationship between credit information sharing and profitability among the Commercial Banks in Kenya. They targeted the 43 commercial banks operating in the country. Descriptive research design was employed. The study used secondary collected from the banks' annual reports and the Central bank's database. Data was analysed using descriptive statistics. The study discovered that high interest rates and slowness in financing of loans results from the SMEs lack of history on credit-worthiness. 5 million Kenyan shillings is the average loan amount given to SMEs in Kenya. For the SMEs looking for long term access in financing, informational dullness and quality improvement are enhanced by credit scoring. The banks capability to quantify risk limits the SMEs access to credit scoring.

In a Kenyan study, Wambui (2016) evaluated the effect of credit information sharing on the financial performance of commercial banks in Kenya. The research utilized a descriptive research design. For this study, all the 43 commercial banks licensed under the banking Act as at 31 December 2015 in Kenya formed the target population. A census approach was employed since the number of banks were only few. Secondary data was used in this study. The data was collected from CBK annual supervision reports and the banks specific audited accounts. The study used Statistical Package for the Social Sciences (SPSS) to run a regression model that was used to determine effects of sharing of credit information on banks" performance in financial perspective. The study established a significant positive relationship between credit scoring and the banks' performance in financial perspective. The study concluded that failure to share credit information increases credit risk, which in turn reduces banks" performance in financial perspective. The study recommended that management of commercial banks in Kenya should set up appropriate mechanisms to share credit information so hence to reduce credit risk and enhance their performance in financial perspective.

Gakobo (2014) did a study on the effect of credit information sharing on the financial performance of commercial banks in Kenya. He focused on the 43 commercial banks in Kenya. The study used secondary data gathered from the banks' annual reports and the Central bank of Kenya. Data was analyzed using descriptive statistics. The study established that the credit appraisal procedure which is done through credit information sharing affects credit risk reduction of commercial banks in Kenya. Also rules for availing credit ought to be flexible and varying for the different situations. Also, banks ought to consider every factor deemed to be important in appraising the loan.

Muthoni (2014) studied credit information sharing, bank characteristics and the general market financial performance. The study aimed at establishing effects of sharing of credit information on overall performance of the credit market. Data on default and credit availability of commercial banks was gathered for a 5 years period. Descriptive and exploratory research designs were employed to establish effects of credit rating on the performance of all banks in Kenya. Panel data regression was done. The researcher established that sharing of credit information significantly aids the process of determining the borrower's credit rating thereby reducing default rates and hence enhancing the profitability of banking institutions.

Kerage (2014) studied the credit information sharing to interrogate banks' performance in financial perspective. A census survey of all banks operating under banking Act for a 5 years period was studied. Both primary and secondary data was analyzed. Multiple regression 
analysis was carried out. The researchers established that sharing the debtors" details with the bureau drastically improve bank's financial performance. Multiple regression was developed to determine the relationship. It is 16 established that $87 \%$ variations of banks" profitability is explained by volume of loans, level of non-performing loans, the interest rates charged and the total operating costs.

Munee (2013) carried out a research on effects of sharing of credit information on financial faring of Kenyan banks. A regression analysis was done on total nonperforming loans, number of reports pulled from the bureaus and return on assets. The findings showed that credit information sharing and banks" performance in financial perspective are positively related. Similarly, Koros (2015) studied the effect of CIS on the general credit market financial performance narrowing down on commercial banks. A census study of the 43 commercial banks' secondary data was collected between 2008 and 2014. Descriptive research design was employed and a regression analysis done. A positive relationship was established between credit rating and credit market financial performance of the commercial banks.

Similarly, Mugwe (2015) investigated the effect of credit information sharing on the performance of commercial banks in Kenya. Data was collected from the 43 commercial banks in Kenya for the period between 2005 and 2014. The study adopted a correlational research design. The findings of the study were that the return on equity, return on assets and net interest margin had an upward trend after the licensing of Credit Reference Bureaus (2010 to 2014) compared to a downward trend for the period before the initiation of credit information sharing (2005 to 2009). From 2010 to 2014, non-performing loans also remained below 5\% and the net interest margin was above $6 \%$ for the same period. Through the regression model, it was found that credit rating positively and significantly influenced the banks' profitability.

These studies nonetheless focused on commercial banks, some of which have been in existence for a long time and have huge financial and asset base, as opposed to Saccos most which have barely any assets and therefore their performance largely depends on lending. In another study, Njeru and Ondabu (2015) evaluated the effect of loan repayment on financial performance of deposit taking Saccos in Mount Kenya Region. The target population of the study was all the thirty licensed deposit taking SACCOs in Mount Kenya Region. The sampling technique employed was simple random sampling and the sample size was 92 respondents. The study adopted a descriptive survey. Primary quantitative data was collected by use of selfadministered structured questionnaires. The researcher also used secondary data derived from the audited financial statement of the SACCOs and the regulator (SASRA). The data collected was analyzed, with respect to the study objectives, using both descriptive and inferential statistics. A significant relationship was established between loan repayment and financial performance of deposit taking Saccos in Mount Kenya Region. The researcher concluded that there is need for the regulator to introduce credit policy for the sector, this will help in controlling credit risks among the SACCOs in the sector and reduce credit exposure on guarantors. Currently huge percentage of credit risk is on the guarantors but since the sector is on upward trend on growth, there is need to strengthen the sector by adoption of better and efficient credit management system and will ensure the sector is competitive across the Kenyan financial sector.

The above empirical studies done in the area of credit information sharing regarding its effect on performance of Saccos were inconclusive. The idea underlying credit information sharing is that "the best predictor of future behavior is past behavior" (Miller, 2003). In spite of these propositions there have been mixed findings from these studies e.g. Turner and Varghese (2008) found a positive link between credit information sharing and banks financial 
performance, Nasieku and Ngugi (2016) found a positive relationship between repayment and the performance of the banks while Giannetti, Jentzsch, and Spagnolo (2010) found no relationship between credit information sharing and banks' performance. Furthermore, not enough studies had been done on the effect of credit information sharing on performance of Saccos, and specifically no study had focused on the effect of credit information sharing on the performance of credit among Saccos in Kenya. This study therefore undertook to fill this gap by finding out the effect of credit information sharing on performance among Saccos in Kenya.

\section{METHOD}

The study adopted a descriptive research design a target population of 60 Saccos registered with the Credit Reference Bureau and with their head offices in Nairobi Kenya, the target population being the credit managers as the respondents. The study population being small, census was applied. The data collection instrument was questionnaire. The study's procedure of data collection was drop and pick method. Piloting was done for testing the validity and reliability of the study. Data was coded, edited and organised to bring a meaning to it. and analysed using descriptive and inferential statistics, which included a regression model and correlation analysis. Secondary data analysis showed the trend of performance of the Saccos for the years 2015 to 2017. Multiple regression analysis was used to establish the relationship between the independent variables and the dependent variable and the strength upon which the independent variables affected the dependent variable.

\section{DISCUSSION}

Credit Information Sharing is the exchange of information on client financial history, the information contained is on borrowers' characteristics which include the credit history, credit worthiness and current debt level of the borrower (Jappelli \& Pagano, 2010). Sharing of credit information can make an important contribution to the development of the financial system which is an important determinant of economic growth (Furletti, 2012). Judgment by a creditor on an individual or business' current and future ability and inclination to honor an obligation as agreed (Ozdemir \& Boran, 2008).

The study sought to assess the effect of credit rating on performance of Saccos in Kenya. The findings are presented in a five point Likerts scale where $S A=$ strongly agree, $A=$ agree, $\mathrm{N}=$ neutral, $\mathrm{D}=$ disagree, $\mathrm{SD}=$ strongly disagree and $\mathrm{T}=$ total.

From table 4.1 below, the respondents were asked whether the institution relies on the applicants current debt level when appraising credit allocation. The distribution of findings showed that 12.0 percent of the respondents strongly agreed, 39.0 percent of them agreed, 30.0 percent of the respondents were neutral, 10.0 percent disagreed while 9.0 percent of them strongly disagreed. These findings implied that the institution relies on the applicant's current debt level when appraising credit allocation.

The respondents were also asked whether the sacco gathers information from the institutions where loans were borrowed previously by the applicant before advancing a loan. The distribution of the responses indicated that 30.0 percent of the respondents strongly agreed to the statement, 30.0 percent of them agreed, 3.0 percent of them were neutral, 21.0 percent of them disagreed while 16.0 percent of them strongly disagreed to the statement. These findings implied that the Saccos gather information from the institutions where loans were borrowed previously by the applicant before advancing a loan. In a study carried out in Tunisia on information sharing and information acquisition in the country's credit markets by Karapetyan and Stacescu (2010), it was established that information sharing provide more accurate 
lending decisions, provide higher welfare, which leads to an increased locus on relationship banking, and favor informationally opaque borrowers.

The respondents were also asked whether low default rate would result from lending to borrowers based solely on all credit suppliers (positive information) would increase credit approval by Saccos. The distribution of the responses indicated that 25.0 percent of the respondents strongly agreed to the statement, 32.0 percent of them agreed, 8.0 percent of them were neutral, 18.0 percent of them disagreed while 17.0 percent of them strongly disagreed to the statement. These findings implied that low default rate would result from lending to borrowers based solely on all credit suppliers (positive information) would increase credit approval by Saccos.

The respondents were further asked whether our Saccos forwards list of credit defaulters (negative information) only to credit reference bureau. The distribution of the responses indicated that 29.0 percent of the respondents strongly agreed to the statement, 24.0 percent of them agreed, 10.0 percent of them were neutral while 22.0 percent and 15.0 percent of them disagreed strongly and disagreed to the statement respectively. These findings implied that our Saccos forwards list of credit defaulters (negative information) only to credit reference bureau. In the past, credit scoring focused on measuring the risk that a customer would not fulfil his/her financial obligations and run into payment arrears. More recently, credit scoring evolved to loss and exposure risk as well (Glennon et al., 2008).

The respondents were further asked whether the Saccos use credit rating and looks for evidence of an individual's ability to repay the loan, in the form of past earnings or income projections. The distribution of the responses indicated that 40.0 percent of the respondents strongly agreed to the statement, 23.0 percent of them agreed, 5.0 percent of them were neutral, 20.0 percent of them disagreed while 12.0 percent of them strongly disagreed to the statement respectively. These findings implied that the Saccos uses credit rating and looks for evidence of an individual's ability to repay the loan, in the form of past earnings or income projections.

The respondents were asked whether organizations forwards lists of credit defaults, overall loan exposure, guarantees and data from past credit history to credit reference bureau. The distribution of the responses indicated that 42.0 percent of the respondents strongly agreed to the statement, 30.0 percent of them agreed, 18.0 percent of them were neutral, another 10.0 percent of them disagreed while none of them strongly disagreed to the statement respectively. These findings implied that organizations forwards lists of credit defaults, overall loan exposure, guarantees and data from past credit history to credit reference bureau.

Finally, the respondents on whether the information shared on the current debt level of the customer determine whether to lend or not to lend and the amount of loan to advance strongly agreed that the information shared on the current debt level of the customer determine whether to lend or not to lend and the amount of loan to advance. Gietzen (2016) in a study done in Cote D'voire posited that information sharing efficiently mitigates adverse selection problems since information sharing facilitates tracing borrowers who switch banks. 
Table 4.1 Effect of credit rating on performance of Saccos

\begin{tabular}{|c|c|c|c|c|c|c|c|}
\hline Statements & $\%$ & SA & $\mathbf{A}$ & $\mathbf{N}$ & D & SD & Total \\
\hline $\begin{array}{l}\text { The institution relies on the } \\
\text { applicants current debt level when } \\
\text { appraising credit allocation }\end{array}$ & $\%$ & 12.0 & 39.0 & 30.0 & 10.0 & 9.0 & 100 \\
\hline $\begin{array}{l}\text { The Saccos gathers information } \\
\text { from the institutions where loans } \\
\text { were borrowed previously by the } \\
\text { applicant before advancing a loan }\end{array}$ & $\%$ & 30.0 & 30.0 & 3.0 & 21.0 & 16.0 & 100 \\
\hline $\begin{array}{l}\text { Low default rate would result from } \\
\text { lending to borrowers based solely } \\
\text { on all credit suppliers (positive } \\
\text { information) would increase credit } \\
\text { approval by Saccos }\end{array}$ & $\%$ & 25.0 & 32.0 & 8.0 & 18.0 & 17.0 & 100 \\
\hline $\begin{array}{l}\text { Our Saccos forwards list of credit } \\
\text { defaulters (negative information) } \\
\text { only to credit reference bureau }\end{array}$ & $\%$ & 29.0 & 24.0 & 10.0 & 22.0 & 15.0 & 100 \\
\hline $\begin{array}{l}\text { The Saccos uses credit rating and } \\
\text { looks for evidence of a an } \\
\text { individual's ability to repay the } \\
\text { loan, in the form of past earnings or } \\
\text { income projections }\end{array}$ & $\%$ & 40.0 & 23.0 & 5.0 & 20.0 & 12.0 & 100 \\
\hline $\begin{array}{l}\text { Organizations forwards lists of } \\
\text { credit defaults, overall loan } \\
\text { exposure, guarantees and data from } \\
\text { past credit history to credit } \\
\text { reference bureau }\end{array}$ & $\%$ & 42.0 & 30.0 & 18.0 & 4.0 & 4.0 & 100 \\
\hline
\end{tabular}

\section{Inferential Statistics \\ Pearson Correlation}

The study sought to establish the strength of the relationship between independent and dependent variables of the study. Pearson correlation coefficient was computed at 95 percent confidence interval (error margin of 0.05). Table 4.10 illustrates the findings of the study.

Table 4.2 Correlation Matrix

\begin{tabular}{llr}
\hline & & Performance of Saccos \\
\hline \multirow{2}{*}{ Credit rating } & Pearson Correlation & $.634^{* *}$ \\
& Sig. (2-tailed) & .000 \\
& $\mathrm{~N}$ & 54 \\
\hline
\end{tabular}

As shown on Table 4.2 above, the p-value for credit rating was found to be 0.000 which is less than the significant level of $0.05,(\mathrm{p}<0.05)$. The result indicated that Pearson Correlation coefficient (r-value) of 0.634 , which represented an average, positive relationship between credit rating on performance of Saccos.

\section{Multiple Linear Regression}

Multiple linear regressions were computed at 95 percent confidence interval 0.05 margin error) to show the multiple linear relationships between the independent and dependent variables of the study.

\section{Coefficient of Determination $\left(\mathbf{R}^{2}\right)$}

Table 4.3 shows that the coefficient of correlation (R) is positive 0.529 . This means that there is a positive correlation between credit information sharing and performance of Saccos in Kenya. The coefficient of determination (R Square) indicates that $28.3 \%$ of performance of Saccos in Kenya is influenced by credit information sharing. The adjusted $\mathrm{R}^{2}$ however, indicates that 
$26.5 \%$ of performance of Saccos in Kenya is influenced by credit information sharing leaving $73.5 \%$ to be influenced by other factors that were not captured in this study.

Table 4.3 Model Summary

\begin{tabular}{|c|c|c|c|c|}
\hline Model & $\mathbf{R}$ & R Square & $\begin{array}{c}\text { Adjusted R } \\
\text { Square }\end{array}$ & Std. Error of the Estimate \\
\hline 1 & $.623^{a}$ & 285 & .253 & 5.0162 \\
\hline
\end{tabular}

a. Predictors: (Constant), credit rating

\section{Analysis of Variance}

Table 4.4 shows the Analysis of Variance (ANOVA). The p-value is 0.000 which is $<0.05$ indicates that the model is statistically significant in predicting how credit information sharing affects performance of Saccos in Kenya. The results also indicate that the independent variables are predictors of the dependent variable.

Table 4.4 ANOVAa

\begin{tabular}{llcrrrl}
\hline Model & & $\begin{array}{c}\text { Sum of } \\
\text { Squares }\end{array}$ & df & \multicolumn{1}{c}{$\begin{array}{c}\text { Mean } \\
\text { Square }\end{array}$} & F & Sig. \\
\hline \multirow{2}{*}{1} & Regression & 684.733 & 3 & 103.605 & 30.127 & $.000^{\mathrm{b}}$ \\
& Residual & 1658.131 & 51 & 17.661 & & \\
& Total & 2342.863 & 54 & & & \\
\hline
\end{tabular}

\section{Regression Coefficients}

From the Coefficients table (Table 4.5) the regression model can be derived as follows:

$$
Y=43.431+0.512 X_{1}
$$

The results in table 4.5 indicate that all the independent variables have a significant positive effect on performance of Saccos. The most influential variable is repayment with a regression coefficient of 2.113 ( $\mathrm{p}$-value $=0.000$ ), followed by credit rating with a coefficient of $0.512(\mathrm{p}$ value $=0.000$ ).

Table 4.5 Regression Coefficients

\begin{tabular}{|c|c|c|c|c|c|c|}
\hline \multirow{2}{*}{\multicolumn{2}{|c|}{ Model }} & \multicolumn{2}{|c|}{$\begin{array}{l}\text { Unstandardized } \\
\text { Coefficients }\end{array}$} & \multirow{2}{*}{$\begin{array}{c}\text { Standardized } \\
\text { Coefficients } \\
\text { Beta } \\
\end{array}$} & \multirow[t]{2}{*}{$t$} & \multirow[t]{2}{*}{ Sig. } \\
\hline & & B & Std. Error & & & \\
\hline \multirow[t]{2}{*}{1} & (Constant) & 32.432 & 3.264 & & 43.431 & .000 \\
\hline & Credit rating & .512 & 109 & .606 & 3.809 & .000 \\
\hline
\end{tabular}

\section{Hypothesis Testing Hypothesis One}

$\mathrm{H}_{01}$ : Credit rating does not have a significant effect on performance of Saccos in Kenya.

From Table 4.5 above, credit rating $(\beta=0.512)$ was found to be positively related performance of Saccos. From t-test analysis, the $t$-value was found to be 3.809 and the $\rho$-value 0.000 . Statistically, this null hypothesis was rejected because $\rho<0.05$. Thus, the study accepted the alternative hypothesis and it concluded that credit rating affects performance of Saccos in Kenya. 


\section{CONCLUSION AND RECOMMENDATIONS}

The study sought to assess the effect of credit rating on performance of Saccos in Kenya. Based on the findings the study concluded the following as follows;

Credit rating $(\beta=0.512)$ was found to be positively related performance of Saccos. From t-test analysis, the $t$-value was found to be 3.809 and the $\rho$-value 0.000 . Statistically, this null hypothesis was rejected because $\rho<0.05$. Thus, the study accepted the alternative hypothesis and it concluded that credit rating affects performance of Saccos in Kenya.

Based on the findings, the researcher recommended the following:

The management of Saccos should encourage the exercise of gathering information from the institutions where loans were borrowed previously by the applicant before advancing a loan to avoid low default rate and forward lists of credit defaults, overall loan exposure, guarantees and data from past credit history to Credit Reference Bureau for reference.

The management of Saccos should manage their records and files to avoid inaccuracies by having regular cross check the credit information held to ensure it reflects the correct current status of the affected individuals. The Saccos should monitor borrowers and liaises with the credit reference bureaus to get information on borrowers in order to reduce default risk taking into account the repayment history of the applicant when advancing a loan.

\section{References}

Aduda, J., \& Gitonga, J. (2011). The Relationship between Credit Risk Management and Profitability among the Commercial Banks in Kenya. Journal of Modern Accounting and Auditing, 7(9), 934-946.

Bakeri, A., Bakar, A., \& Abdoulaye, K. (2010). Collection development for the digital age: The case of Malaysia. In International Conference on Asian Digital Libraries (pp. 366-378). Berlin, Heidelberg: Springer.

Batiz-Lazo, B., \& Woldesenbet, K. (2006). The dynamics of product and process innovation in UK banking. International Journal of Financial Services Management, 1(4), 400-421.

Black, B. (2010). The corporate governance behavior and market value of Russian firms. Emerging Markets Review, 2(2), 89-108.

Boudriga, A., Boulila, N., \& Jellouli, S. (2009). Does Bank Supervision affect Non-performing Loans: Cross-Country Determinants Using Aggregate Data. Journal of Finance Management, 21(4), 56-61.

Bonaya, D.A. (2012). The effect of credit information sharing on loan performance of commercial banks in Kenya. Journal of Credit Risk, 5(6), 41-49.

Brown, M., \& Zehnder, C. (2016). Credit Reporting, Relationship Banking and Loan Repayment. Journal of Money, Credit and Banking, 39(8), 1883-1918.

Brown, M., Jappelli, T., \& Pagano, M. (2017). Information Sharing and Credit: Firm-Level Evidence from Transition Countries. Working Paper No. 178. Centre for Studies in Economics and Finance - University of Salerno.

Central Bank of Kenya, (2017). Bank Supervision Annual Reports 2017.

Cowan, C.D., \& Cowan, A.M. (2006). A Survey Based Assessment of Financial Institution Use of Credit Scoring For Small Business Lending in Canada. Journal of Money, Credit and Banking, 39(6), 178-206.

Donge, J.A. (2012). Credit bureau policy and sustainable reputation effects in credit markets. Economica, 16(8), 461-478.

Furletti, M.J. (2012). An overview and history of credit reporting. Retrieved from http://papers.ssrn.com/sol3/papers.cfm?abstract_id=927487

Giannetti, R., Jentzsch, T., \& Spagnolo, A. (2010). The effect of credit information accuracy on the performance of banks in Norway. Journal of Finance, 32(2), 371-387.

Gietzen, T. (2016). The Impact of Credit Information Sharing on Interest Rates. Working Papers on Finance No. $2016 / 12$. Swiss Institute of Banking and Finance. Available at http://ssrn.com/abstract=2798531. Retrieved on 18 September 2018.

Gitahi, R. (2013). Effect of Repayment on the Level of Non-Performing Loans in Commercial Banks in Kenya. Unpublished MBA Thesis, University of Nairobi. 
Glennon, D., Kiefer, N.M., Larson, E.C., \& Choi, H. (2008). Development and Validation of Credit Scoring Models. Journal of Credit Risk, 23(4), 56-78.

Jappelli, T., \& Pagano, M. (2010). Information Sharing, Lending and Defaults: Cross-Country Evidence. Journal of Banking and Finance, 26(10), 2017-2045.

Kabiru, P. (2014). The effects of listing of loan defaulters by credit reference bureaus on non-performing loans of commercial banks in Kenya. Unpublished MBA Thesis, University of Nairobi.

Kamau, M. K., Namiinda, B., \& Buluma, F. (2016). Effects of System Integrity in Credit Information Sharing on Management of Credit Risk in Commercial Banks in Nakuru Town, Kenya. IOSR Journal of Business and Management, 18(2), 52-57.

Karapetyan, A., \& Stacescu, B. (2010). Information Sharing and Information Acquisition in Credit Markets. Working Paper 2010/24. Prague: Norges.

Kerage, P.M. (2014). Credit Information Sharing and Performance of Commercial Banks in Kenya. Global Journal of Commerce and Management Perspective, 3(6), 18-23.

Kiage, E., \& Musyoka, F.M. (2015). Influence of positive credit information sharing determinants on the financial performance of commercial banks in Kenya: A survey of commercial banks in Kisii Town. International Journal of Economics, Commerce and Management, 3(3), 1-13.

Kisengese, W. K. (2014). The Impact of Credit Information Sharing on the Level of Non - Performing Loans of Commercial Banks in Kenya. Unpublished MBA Thesis. United States International University-Africa.

Klein, D. (2012). Promise Keeping in the Great Society: A Model of Credit Information Sharing. Economics and Politics, 7(13), 117-136.

Klomp, S., \& Clear, A. (2016). Senior Management Perceptions of CSR Impact: Long-term Investment for Social Good or Necessary Cost? In Disciplining the Undisciplined? (pp. 177-191). Boston: Springer.

Kusi, B.A., \& Ansah-Adu, K. (2015). Credit Information Sharing and its Impact on Access to Bank Credit across Income Bracket Groupings. International Journal of Economics, Finance and Management, 4(4), 138-145.

La Porta, H., Florencio, T., Andrei, M., \& Robert, E.(2007). Informational asymmetries, financial structure and financial Intermediation. Journal of Finance, 32(2), 371-87.

Mabrouk, A., \& Mamoghli, C. (2010). Dynamic of financial innovation and performance of banking firms: Context of an emerging banking industry. International Research Journal of Finance and Economics, 5(6), 20-26

McIntosh, C., \& Wydick, B. (2014). A Decomposition of Incentive and Screening Effects in Credit Market Information Systems. Journal of Finance and Management, 9(4), 67-73.

Mugwe, M.W. (2015). The Effect of credit information sharing on the performance of commercial banks in Kenya. International Journal of Business and Commerce, 5(3), 41-63.

Munee, T. A (2013). Effect of Credit Information sharing on the Financial Performance of Commercial banks in Kenya. Unpublished MBA Project. University of Nairobi.

Muthoni, J. M. (2014). Credit Information Sharing, Bank Characteristics and Credit Market Financial Performances in Kenya. Unpublished PhD Thesis, Kenyatta University.

Mwangi, B.W., \& Muturi, W. (2016). Effects of credit risk management on loan repayment performance of commercial banks in Kenya. International Academic Journal of Economics and Finance, 2(2), 1-24.

Mwengei, K.B. (2013). Assessing the Factors Contributing to Non-Performance Loans in Kenyan Banks. European Journal of Business and Management, 5(32), 155-162.

Nasieku, T., \& Ngugi, R. W. (2016). Credit Information Sharing and Credit Risk Reduction in Kenya Commercial Banks. Journal of Social Sciences Research, 10(1), 222-226.

Njeri, A.M. (2016). Effect of lending practices on financial performance of commercial banks in Kenya: A survey of selected banks within Nairobi. MBA Thesis, University of Nairobi.

Njeru, D.M., \& Ondabu, I.T. (2015). Effect of loan repayment on financial performance of deposit taking Saccos in Mount Kenya Region. International Journal of Innovation and Applied Studies, 10(4), 1238-1244.

Ocharo, O. F. (2013). The Effect of Credit Information Sharing on the Non-Performing Loans among Commercial Banks in Kenya. Unpublished MSc in Finance Project, University of Nairobi.

Oludhe, K. (2011). The effect of credit risk management on financial performance of commercial banks in Kenya. Unpublished MBA Thesis, University of Nairobi.

Omar, A.K., \& Makori, D. (2018). Credit information sharing and financial performance of commercial banks in Kenya. International Academic Journal of Economics and Finance, 3(2), 160-178. 
Omitogun, O., Olanrewaju, D., \& Alalade, Y. (2016). Loans Default and Return on Assets in the Nigerian Banking System. International Journal of Economics and Financial Research, 2(4), 65-73.

Rukwaro, M.W. (2011). Credit rationing by micro finance institutions and its influence on the operations of small and micro enterprises. MBA Thesis, University of Nairobi.

Sacerdoti, E. (2010). Improving credit information, bank regulation and supervision: On the role and design of public credit registries (Vol. 3443). New York: World Bank Publications.

Stiglitz, J.E., \& Weiss, A. (2008). Credit rationing in markets with imperfect information. American Economic Review, 71(12), 393-410.

Turner, M., \& Varghese, R. (2007). Economic Fairness through Smarter Lending: Some factors to consider on the eve of Brazilian credit reporting reform. Rio de Janeiro: Gredner Press.

Van Donge, J.A. (2012). Credit bureau policy and sustainable reputation effects in credit markets. Economica, 3(1), 461478.

Wanjohi, M.K. (2015). Credit reference bureau strategy and loan performance at the Commercial Bank of Africa in Kenya. Unpublished MBA Paper, University of Nairobi.

Warue, B.N. (2013). The effects of bank specific and macroeconomic factors on nonperforming loans in commercial banks in Kenya: A comparative panel data analysis. Advances in Management \& Applied Economics, 3(2), 135-164. 